\title{
Performance of nonionic surfactants derived from tannic acid in preventing the acidic dissolution of carbon steel
}

\author{
Nabel A. Negm ${ }^{1 \#}$, Emad A. Badr ${ }^{1}$, Salah M Tawfik ${ }^{1}$, Ahmad M.F El Farargy $^{2}$ \\ ${ }^{1 .}$ Egyptian petroleum research institute, Nasr city, Cairo, EGYPT \\ Faculty of Science, ZagazigUniversity, Zagazig, EGYPT.
}

\begin{abstract}
Corrosion inhibition tendency of four modified nonionic tannic acid derivatives containing dodecyl, hexadecyl, octadecyl and oleyl chains on carbon steel was investigated using gravimetric measurements, polarization and electrochemical impedance spectroscopy (EIS). The effect of concentration and immersion time was studied. The results show that the synthesized inhibitors act as efficient inhibitor for the corrosion of carbon steel in $0.5 \mathrm{M} \mathrm{H}_{2} \mathrm{SO}_{4}$. Inhibition efficiency ( $\eta \%$ ) increases with the inhibitor concentration, and the maximum $\eta$ $\%$ values at 400 ppm by weight are $94.4 \%-96.4 \%$ at $25{ }^{\circ} \mathrm{C}$.The adsorption of the different inhibitors on carbon steel surface obeys Langmuir adsorption isotherm. The inhibitors act as mixed-type inhibitor in $0.5 \mathrm{M} \mathrm{H}_{2} \mathrm{SO}_{4}$ and their inhibition on carbon steel is caused by physical adsorption (physisorption).EIS spectra exhibit one capacitive loop which indicates that the corrosion reaction is controlled by charge transfer process. The addition of the inhibitors to $0.5 \mathrm{M} \mathrm{H}_{2} \mathrm{SO}_{4}$ solutions enhances $R_{t}$ values while reduces $C_{d l}$ values.
\end{abstract}

Keywords: Nonionic surfactant, corrosion inhibition, acidic corrosion.

\section{Introduction}

Corrosion is costly and severe materials science problem. The corrosion of carbon steel is the most common form of corrosion, especially in acid solution. Acidic corrosion has received a considerable attention as a result of its industrial importance, for example in the chemical cleaning and processing, oil well acidizing, petrochemical industry. Steel during painting, electroplating, phosphate coating and cold rolling must have a clean surface from oxides and scales. Therefore, steel is immersed in an acid solution called acid pickling bath. Hydrochloric and sulfuric acid solutions are widely used in pickling bath of steel. Because of the general aggressiveness of these acids, organic inhibitors are commonly used to reduce the corrosion on metallic materials (Obot and Egbedi, 2010; Behpour, 2008; Hosseini and Azimi, 2009). Among the inhibitors which are effective in acid solutions there are nitrogen containing compounds such as amines (Luo et al., 1998),pyridazine(Chetouani et al., 2003), quinoline and pyridine (Li et al., 2008), pyrazole(Tebbji et al., 2005), pyrazine(Bouklah et al., 2005), acridine(Granese et al., 1992), benzimidazole(Cruz et al., 2005) and triazoles(Pardave et al., 2012; Zhou et al., 2012; Hassan et al., 2007). Several studies have shown that heterocyclic compounds and their derivatives display good inhibiting effects on carbon steel and copper corrosion in acid solutions (Godec, 2010; Negm and Zaky, 2008; Quartarone et al., 2006; Quartarone et al., 2008; Lebrini et al., 2010). It is generally accepted that the primary step in the protecting action of an inhibitor in the acid metal corrosion is adsorption of the organic molecule onto the metal surface, which is usually oxidefree. The adsorption requires the existence of attractive forces between the metal surface and the organic inhibitors. Accordingly, adsorption isphysisorption, chemisorption or a combination of both (Asefi et al., 2010; Asefi et al., 2009). Physisorption is anelectrostatic interaction between inhibitor ions and the charged metal surface. Recently the trends of the scientific research have been directed to the environmental protection using green chemistry products. This was applied specifically in the field of corrosion, resulting in the decreasing use of chemical corrosion inhibitors and also in the developing of new environmentally friendly inhibitors. Tannic acid which occurs in several plants including coffee, tea, and Mangrove trees, is a natural product and has low environmental impact (Negm et al., 2012). Tannic acid is used in the conservation of ferrous metal objects to passivate and inhibit corrosion. Tannic acid reacts with the corrosion products to form a more stable compound, thus preventing further corrosion process. After treatment with the tannic acid, the residue remains on the surface will be hydrated and prevents or retards further corrosion. Tannic acid treatment for conservation of iron is very effective and widely used. Tannins form chelates with iron and other metallic cations due to the presence of hydroxyl groups on the aromatic rings. Rust protection properties result from the reactions of polyphenolic parts of the tannin molecule with ferric ions form a highly cross linked network of ferric-tannate(Jaen et al., 1999). Gust, (1991) has reported that a mixture of mono- and bi-complexes was formed as a result of the reaction between the iron rust phase components and tannins in aqueous solution. Similar mixtures were also observed during reaction of extracts from Mangrove barks of Panama (Rahim et al., 2008) with ferrous and ferric salts. Natural products such as Henna extract (Lawsoniainermis) and its main constituents (lawsone, gallic acid, $\square$-glucose and tannic acid) were investigated as corrosion inhibitor for corrosion of mild steel in $1 \mathrm{M} \mathrm{HCl}$ 
solution using electrochemical and surface analysis methods (Ostovari et al., 2009). The aim of the present study was to study the inhibiting action of modified tannic acid derivatives in the nonionic form on the corrosion of carbon steel in $1 \mathrm{M}$ sulfuric acid solution using gravimetric and electrochemical techniques. The adsorption behaviour of the inhibitors wasanalysed in order to choose the appropriate adsorption isotherm and determine the energy of adsorption.

\subsection{Inhibitors}

\section{Experimental}

The synthesis of the tested inhibitors $\left(\mathrm{TN}_{15} \mathrm{D}, \mathrm{TN}_{15} \mathrm{H}, \mathrm{TN}_{15} \mathrm{O}, \mathrm{TN}_{15} \mathrm{~L}\right)$ was described briefly in our recent study (Negm et al., 2012). The chemical structures of the different inhibitors are shown in Fig. 1.

\subsection{Materials}

Tests were performed on carbon steel of the following composition (wt.\%): $0.11 \% \mathrm{C}, 0.45 \% \mathrm{Mn}$, $0.04 \% \mathrm{P}, 0.05 \% \mathrm{~S}, 0.25 \% \mathrm{Si}$ and the remainder is $\mathrm{Fe}$.

\subsection{Weight loss method}

Weight loss measurements were performed (in triplicate) on the carbon steel samples with a rectangular form with a total area of $37 \mathrm{~cm}^{2}$ in $0.5 \mathrm{M} \mathrm{H}_{2} \mathrm{SO}_{4}$ solution with and without addition of different concentrations of $\mathrm{TN}_{15} \mathrm{D}, \mathrm{TN}_{15} \mathrm{H}, \mathrm{TN}_{15} \mathrm{O}, \mathrm{TN}_{15} \mathrm{~L}(50,100,200$ and $400 \mathrm{ppm}$ by weight). Before the measurement, the carbon steel samples were abraded by $180,400,600$, and 1200 grades of emery paper. They were degreased with acetone and rinsed in distilled water several times. Then they were immersed in $1 \mathrm{M} \mathrm{HCl}$ solution for $10 \mathrm{~s}$ (chemical method to remove rust products), rinsed with distilled water two times and finally dried. After weighing accurately, each sample is placed in the acid solution $(500 \mathrm{~mL})$ for different immersion time intervals of 3,6 and $24 \mathrm{~h}$ at $25^{\circ} \mathrm{C}$. Then, the surface of each specimen was cleaned by double distilled water followed by rinsing with acetone, dried and weighed to calculate the loss in weight (w) of each specimen. For each experiment, a freshly prepared solution was used, and the solution temperature was thermostatically controlled. The aggressive solutions $\left(0.5 \mathrm{M} \mathrm{H}_{2} \mathrm{SO}_{4}\right)$ were prepared by dilution of an analytical grade $\mathrm{H}_{2} \mathrm{SO}_{4}$ with double distilled water. The corrosion rate $\left(\mathrm{C}_{\mathrm{r}}\right)$, surface coverage $(\theta)$ and inhibition efficiency $(\eta \%)$ were determined by using Eq. (1)-(3) (ASTM-G31-72, 1990):

$$
\begin{array}{r}
C_{r}=\frac{w_{o}-w_{i}}{A t}(1) \\
\theta=\frac{w_{o}-w_{i}}{w_{o}}(2) \\
\eta \%=\frac{w_{o}-w_{i}}{w_{o}} \times 100
\end{array}
$$

where, $w_{i}$ and $w_{o}$ are the weight loss values in presence and absence of inhibitor, respectively. A is the total area of the specimen and $t$ is the immersion time.

\subsection{Polarisation measurements}

Electrochemical measurements were carried out using a Voltalab-40 Potentiostat PGZ-301 (France). A conventional cylindrical glass cell of $250 \mathrm{~mL}$ with three electrodes was used. A platinum sheet of $2 \mathrm{~cm}^{2}$ area and saturated calomel electrode (SCE) were used as auxiliary and reference electrodes, respectively. The working electrode in the form of disc cut from carbon steel with an area of $0.8 \mathrm{~cm}^{2}$ was embedded with epoxy except the working surface. Potentiodynamic polarisation curves of the tested inhibitors were obtained by changing the potential automatically from -200 to $+200 \mathrm{mV}$ versus open circuit potential (OCP) with the scan rate of $2 \mathrm{mV} \mathrm{s}^{-1}$. The inhibition efficiency ( $\eta \%$ ) was calculated using Eq. (4) as follows (ASTM G3-89, 1994):

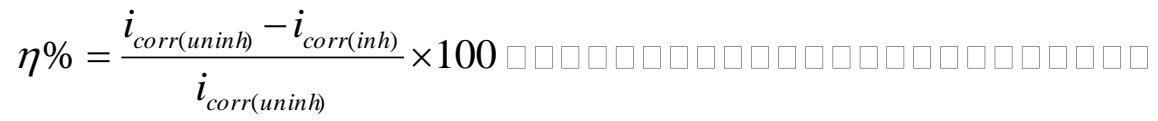

wherei $i_{\text {corr(uninh) }}$ andi $_{\text {corr(inh) }}$ are the corrosion current density values without and with the tested inhibitors.

\subsection{Electrochemical impedance spectroscopy (EIS)}

EIS measurements were carried out using a Voltalab-40 Potentiostat PGZ-301 attached with Voltamaster software program (Hassan, 2005). The measurements were carried out using AC signal $(10 \mathrm{mV})$ peak to peak at the open circuit potential (OPC) in the frequency range of $100 \mathrm{kHz}$ to $10 \mathrm{mHz}$. The inhibition 
efficiencies $(\eta \%)$ of the tested inhibitors were calculated from the values of $R_{t}$ at 50,100, 200 and $400 \mathrm{ppm}$ by weight at $25^{\circ} \mathrm{C}$ using Eq. (5) (Hsu and Mansfeld, 2001):

$$
\eta \%=\left(1-\frac{R_{t}}{R_{t}^{\circ}}\right) \times 100
$$

\section{Results and Discussion}

The data obtained from the weight loss measurements were: corrosion rate $\left(\mathrm{C}_{\mathrm{r}}\right)$, surface coverage $(\theta)$ and inhibition efficiencies $(\eta \%)$ in presence of different concentrations of the inhibitors $(50,100,200$ and 400 ppm by weight) using Eq. (1)-(3) at $25^{\circ} \mathrm{C}$ were listed in Table 1. The corrosion inhibition efficiencies of $\mathrm{TN}_{15} \mathrm{D}$, $\mathrm{TN}_{15} \mathrm{H}, \mathrm{TN}_{15} \mathrm{O}, \mathrm{TN}_{15} \mathrm{~L}$ inhibitorsshowedhigh tendency towards retardation of the carbon steel dissolution in 0.5 $\mathrm{M} \mathrm{H}_{2} \mathrm{SO}_{4}$ solution at all concentrations used. The inhibition efficiencies of the inhibitors were gradually increased to reach the maximum value in presence of the different inhibitors at 200 and 400 ppm by weight. While the corrosion rates decrease by increasing the concentration of the tested inhibitor.

The corrosion rates of the carbon steel in presence of the different inhibitors are completely depending on the alkyl chain length attached to the inhibitors at similar concentration. The shorter chain length inhibitor, as represented in case of $\mathrm{TN}_{15} \mathrm{D}$, has high corrosion rate $\left(\mathrm{C}_{\mathrm{r}}\right)$ of $0.51 \mathrm{mg} \mathrm{cm}^{-2} \mathrm{~h}^{-1}$ at $50 \mathrm{ppm}$ by weight at $25^{\circ} \mathrm{C}$. Replacing the dodecyl chain with hexadecyl $\left(\mathrm{TN}_{15} \mathrm{H}\right)$ and octadecyl chain $\left(\mathrm{TN}_{15} \mathrm{O}\right)$ decreases the corrosion rates considerably to lower values $\left(0.45\right.$ and $0.41 \mathrm{mg} \mathrm{cm}^{-2}$, respectively) at $50 \mathrm{ppm}$ by weight at $25^{\circ} \mathrm{C}$. The presence of the unsaturation centre in the alkyl chain as in case of $\mathrm{TN}_{15} \mathrm{~L}$ decreased the corrosion rate to lower extent at $0.37 \mathrm{mg} \mathrm{cm}^{-2} \mathrm{~h}^{-1}$ at the same concentration. The corrosion process occurs due to the interaction between the metal surface and $\mathrm{H}_{2} \mathrm{SO}_{4}$ solution according toEq. 6, (Godec, 2009):

$$
\mathrm{Fe}+\mathrm{H}_{2} \mathrm{SO}_{4} \rightarrow \mathrm{FeSO}_{4}+\mathrm{H}_{2}
$$

The role of the corrosion inhibitors is to decrease the dissolution of the metal in the acid solution. That role is precededby adsorption of the inhibitor molecules at the metal surface which decreases the extent of metal interaction with the corrosive ions(Negm et al., 2011). The inhibitors under investigation have high tendency towards adsorption at the different interfaces due to their high surface activity (Negm et al., 2012). The inhibitor molecules form a protective layer at the metal surface which decreases the corrosion rate (Quraishi and Jamal, 2000). This protective layer is formed due to the adsorption of the charged centres of the inhibitor molecules on the metal surface, while the alkyl chains directed to the polar medium. The organic nature of the alkyl chains prevents the penetration of the aggressive ions to the metal surface. Longer alkyl chains cover larger area at the interface and also increases the density of the protective layer. That explains the high inhibition efficiency of the octadecyl derivative $\left(\mathrm{TN}_{15} \mathrm{O}\right)$ and the relatively low inhibition efficiency of dodecyl derivative $\left(\mathrm{TN}_{15} \mathrm{D}\right)$, Table 1. The oleate derivative has higher tendency towards adsorption at the interface (Negm et al., 2012), which is accompanied by the lowest corrosion rate and highest inhibition efficiency, Table 1 .

The inhibitor concentration plays aremarkable role on the inhibition of the carbon steel corrosion in presence of the tested inhibitors. It is clear from Table 1 that at similar immersion time, $\mathrm{C}_{\mathrm{r}}$ values decrease considerably by increasing the inhibitor concentration from 50 to $400 \mathrm{ppm}$ by weight. That can be attributed to the increase in the thickness of the adsorbed layer of the inhibitor molecules on the metal surface by increasing the concentration, which increases $\eta \%$ values.

The immersion time was found to influence the inhibition process of the carbon steel in $1 \mathrm{M} \mathrm{H}_{2} \mathrm{SO}_{4}$ in presence of the different inhibitors. At short immersion time, 1 and $3 \mathrm{~h}$, the surface coverage values were increased noticeably by increasing the concentration. Increasing the immersion time to 6 hdecreases the corrosion rates moderately and consequently a minor increase in the surface coverage is obtained. At $24 \mathrm{~h}$ immersion, the corrosion rates stay almost constant to that obtained in case of $6 \mathrm{~h}$ immersion time, also the effect of the inhibitor concentration is decreased. That is due to the increase of the protective layer thickness by increasing the immersion time. No further adsorption is occurred at $24 \mathrm{~h}$, hence the corrosion rate decreased to its minimum values and the surface coverage stays almost constant, which accompanied by narrow inhibition efficiencies. The corrosion rate of the $\mathrm{TN}_{15} \mathrm{~L}$ inhibitor after $3 \mathrm{~h}$ was $0.14 \mathrm{mg} \mathrm{cm}^{-2} \mathrm{~h}^{-1}$, while increasing the time of immersion to 6 and $24 \mathrm{~h}$ decreases $\mathrm{C}_{\mathrm{r}}$ values to 0.08 and $0.02 \mathrm{mg} \mathrm{cm}^{-2} \mathrm{~h}^{-1}$.

The obtained inhibition efficiencies of the tested inhibitors are ranged between $87.7-90.6 \%$ at the lowest inhibitors concentration (50 ppm by weight) and ranged between $94.4-96.4 \%$ at the highest inhibitors concentration ( $400 \mathrm{ppm}$ by weight). Comparing our values in Table 1 by the values obtained for the nonionic derivatives vanillin as environmentally friendly corrosion inhibitors (in our previous study)(Negm et al., 2011) indicates the good performance of the tannic acid nonionic derivatives as corrosion inhibitors. The adsorption of the tested inhibitors on the metal surface increases by the presence of $\pi$-electrons of aromatic ring and lone pair of electrons of hetero-atoms (N, O, S, and P) (Quraishi et al.,1997). The tested inhibitors are strongly adsorbed at the metal/solution interface due to: (a) the presence of the benzene rings, nonionic chain and the alkyl chains 
within the chemical structure of the inhibitors; (b) the hydroxyl groups in the inhibitor molecules are protonated in the acidic medium to form a positive centre which attracted to the negative sites on the metal surface.

\section{Potentiodynamic polarisation}

The polarization profiles of carbon steel electrode in $0.5 \mathrm{M} \mathrm{H}_{2} \mathrm{SO}_{4}$ solution at $25^{\circ} \mathrm{C}$ in the absence and presence of $\mathrm{TN}_{15} \mathrm{O}$ and $\mathrm{TN}_{15} \mathrm{~L}$ inhibitors as representative samples for the tested inhibitors $\left(\mathrm{TN}_{15} \mathrm{D}, \mathrm{TN}_{15} \mathrm{H}\right.$, $\left.\mathrm{TN}_{15} \mathrm{O}, \mathrm{TN}_{15} \mathrm{~L}\right)$ are shown in Fig. 2a,b. The Electrochemical parameters including corrosion potential $\left(\mathrm{E}_{\text {corr }}\right)$, corrosion current density $\left(i_{\text {corr }}\right)$, anodic and cathodic Tafel slopes $\left(\beta_{\mathrm{a}}, \beta_{\mathrm{c}}\right)$ were obtained from the polarisation curves and listed in Table 2.The anodic and cathodic current-potential curves are extrapolated up to the intersection point where corrosion current density $\left(\mathrm{i}_{\text {corr }}\right)$ and corrosion potential $\left(\mathrm{E}_{\text {corr }}\right) / \mathrm{SCE}$ are obtained (McCafferty, 2005). Inspecting the polarisation data disclosed that increasing the inhibitor concentration decreases the corrosion current density $\left(\mathrm{i}_{\text {corr }}\right)$ and increases the inhibition efficiency $(\eta \%)$ which suggests that the tested inhibitorsare good corrosion inhibitors for carbon steel in $0.5 \mathrm{M} \mathrm{H}_{2} \mathrm{SO}_{4}$.

From the polarisation data listed in Table 2, it is obvious that both cathodicand anodic reactions were inhibited when theinhibitors were added to the solution(Liu et al., 2009; Musa et al., 2010). Furthermore, the anodic and cathodicTafel slopes $\left(\beta_{\mathrm{a}}, \beta_{\mathrm{c}}\right)$ stay almost constantwith inhibitor concentration. That can be explained from the viewpoint of thermodynamics, as the inhibitor molecule is adsorbed onto carbon steel surface, which hindered the acid attack of the metal surface (Lebrini et al., 2005).

In acidic solutions, the anodic reaction of corrosion is the dissolution of $\mathrm{Fe}^{2+}$ ions into the solution, and the cathodic reaction is the discharge of hydrogen ions to hydrogen gas $\left(\mathrm{H}_{2}\right)$. It is apparent from Table 2 that the addition of the inhibitors shifts the corrosion potentials $\left(\mathrm{E}_{\text {corr }}\right)$ towards higher negative direction and anodic $\left(\beta_{\mathrm{a}}\right)$ and cathodic $\left(\beta_{\mathrm{c}}\right)$ Tafel slopes changedfaintly, which indicates the inhibition of both cathodic and anodic reactions(Obot and Egbedi, 2010).The parallel cathodic Tafel curves in Fig. 2a,b reveal that the hydrogen evolution is activation-controlled and also not affected by the presence of the inhibitors (Negm et al., 2012). It is also clear that the values of anodic Tafel slope $\left(\beta_{\mathrm{a}}\right)$ almost remain unchanged (except for some points were moderately changed) in the presence of the different inhibitors. This suggests that the inhibitors were adsorbed onto the metal surface and blocking the reaction sites of the metal surface without affecting the anodic reaction mechanism (Abdel-Rehim et al., 2001). It is reported that the inhibitors affect either the anodic or the cathodic reaction, or both of them (Musa et al., 2010). The inhibitor can be classified as an anodicor cathodic type when the change in $\mathrm{E}_{\text {corr }}$ value is larger than $85 \mathrm{mV}$ ( $\mathrm{Li}$ et al., 2008).The maximum shift in $\mathrm{E}_{\text {corr }}$ in the measurements was $41.5 \mathrm{mV}$ indicating that the inhibitors are mixed type inhibitors. It is seen that $\mathrm{i}_{\text {corr }}$ values decrease sharply with increasing the concentration of the inhibitors from 50 to $200 \mathrm{ppm}$ by weight, while above $200 \mathrm{ppm}, \mathrm{i}_{\text {corr }}$ decrease slowly. This is due to the fact that the inhibitor molecules adsorb on the metal surface, which form a barrier between the metal surface and corrosive surroundings. The thickness of the formed barrier is increased by increasing the inhibitor concentration, which decreases $i_{\text {corr }}$ considerably. The results obtained from the polarisation technique in acidic solution were in good agreement with those obtained from the weight loss method within 5\%. That was reported in the previous studies (Negm et al., 2012). The efficiencies obtained from polarisation measurements were comparable to those obtained from the weight loss measurements after $3 \mathrm{~h}$ because the polarisation measurements were obtained after $3 \mathrm{~h}$ stabilization of the working electrode. At longer immersion time (i.e., at 6 and $24 \mathrm{~h}$ ), the efficiencies obtained from the weight loss measurements were increased (Table 1). That was ascribed to the increase in the layerthickness of adsorbed inhibitor molecules at the interface via increasing the immersion time.

\section{Adsorption isotherm of inhibitors}

The adsorption isotherm provides basic information on the interaction between inhibitor and steel surface.

The obtained results were best fitted by Langmuir adsorption isotherm (Figure 3) according to Eq. (9) which modified to Eq. (7) (Ameer et al., 2010):

$$
\frac{C_{i}}{\theta}=\frac{1}{K_{a d s}}+C_{i}
$$

The straight lines obtained in Figure 3 suggest that the adsorption of inhibitors on carbon steel in $0.5 \mathrm{M}$ $\mathrm{H}_{2} \mathrm{SO}_{4}$ solution follows Langmuir's adsorption isotherm (Noor and Al-Moubaraki, 2008).

The regression coefficients values $\left(\mathrm{R}^{2}>0.999-1.0\right)$ reveal that the adsorption of $\mathrm{TN}_{15} \mathrm{D}, \mathrm{TN}_{15} \mathrm{H}, \mathrm{TN}_{15} \mathrm{O}$, $\mathrm{TN}_{15} \mathrm{~L}$ inhibitors oncarbon steel surface obeys Langmuir adsorption isotherm and the inhibition process is due to the adsorption of inhibitor molecules on the metal surface (Table 3).Meanwhile, the obtained slopes were close to 1, which suggest an associative adsorption of inhibitor molecules at the metal surface (Hegazy et al., 2010). It is well recognized that the first step in inhibition of metallic corrosion is the adsorption of organic inhibitors on the metal/solution interface.That adsorption depends on:chemical structure of the molecule, temperature and 
electrochemical potential at metal/solution interface. In fact, $\mathrm{H}_{2} \mathrm{O}$ molecules adsorb at metal/solution interface, and the adsorption of the inhibitors from the solution regarded as a quasi-substitution process between the organic compounds in the aqueous phase $\left[\mathrm{Org}_{(\mathrm{sol})}\right]$ and water molecules at the electrode surface $\left[\mathrm{H}_{2} \mathrm{O}_{(\mathrm{ads})}\right]$ as represented in Eq. (8) (Valcarce and Vazquez, 2009).

$$
\mathrm{Org}_{(\text {sol) }}+\mathrm{xH}_{2} \mathrm{O}_{\text {(ads) }} \leftrightarrow \mathrm{Org}_{(\text {ads })}+\mathrm{xH}_{2} \mathrm{O}_{\text {(sol) }}
$$

wherex is the number of water molecules replaced by one organic inhibitor.

The equilibrium constant $\left(\mathrm{K}_{\mathrm{ads}}\right)$ of the reaction represented in equation (11)is correlated to the standard free energy of adsorption $\left(\mathrm{G}^{\circ}\right.$ ads $)$ of the inhibitor molecules on the metal surface according to Eq.(9)(Valcarce and Vazquez, 2009; Shukla and Quraishi, 2009):

$$
K_{a d s}=\frac{1}{55.5} e^{\frac{-\Delta G_{a d s}^{\circ}}{R T}}
$$

Generally, the energy values of $-20 \mathrm{~kJ} \mathrm{~mol}^{-1}$ or less negative are associated withan electrostatic interaction between charged molecules and charged metal surface, i.e., physisorption(Bentiss et al., 2005). While, those of $-40 \mathrm{~kJ} \mathrm{~mol}^{-1}$ or more negative regarded as chemisorption, which is formed by sharing or transferringof charges from the inhibitor molecules on the metal surface to form a covalent bonds(Machnikova et al., 2008; Singh and Quraishi, 2009). $\mathrm{G}_{\text {ads }}$ values of the studied systems are ranged between $-32.67 \mathrm{~kJ} \mathrm{~mol}^{-1}$ and $-32.75 \mathrm{~kJ} \mathrm{~mol}^{-1}$, Table 3. These values indicate that the inhibitors are adsorbed on the metal surface via mixed mechanism involves physical and chemical adsorption. Physical adsorption occurs between the active positive centers on the metal surface and the $\pi$-bonds in the benzene ring. Chemical adsorption is due to formation of coordinated bonds between the inhibitor molecules and the d-orbital of Fe on the steel surface through lone pair of electron of $\mathrm{O}$ atoms (Solmaz et al., 2008). The increase in negativity of $\mathrm{G}_{\text {ads }}$ values by increasing the alkyl chain length of the inhibitors is attributed to the role of the chains in the adsorption of the inhibitor molecules on the metal-solution interface (Machnikova et al., 2008; Solmaz et al., 2008).

\section{The electrochemical impedance spectroscopy (EIS)}

The EIS diagrams for the carbon steel in $0.5 \mathrm{M} \mathrm{H}_{2} \mathrm{SO}_{4}$ solution in absenceand presence of various concentrations of the tested inhibitors are given in Fig. 4a,b, which indicates that the Nyquist plot yields adepressed semicircles. The depressed nature of the semicircle is due to the presence of micro roughness and other inhomogeneties of the electrode formed during the corrosion process (McCafferty, 1997; Popova et al., 2003). This implies that corrosion of the carbon steel in $0.5 \mathrm{M} \mathrm{H}_{2} \mathrm{SO}_{4}$ solution mainly controlled by a chargetransferprocess (Achouri et al., 2001; Dehri et al., 2003; Bentiss et al., 2011).The difference in real impedance at lower andhigher frequencies on Nyquist plots is considered asa charge-transferresistance. The charge-transfer resistance $\left(\mathrm{R}_{\mathrm{ct}}\right)$ is corresponded to the resistance between the metal and outerHelmholtz layer.The differencein real impedance at lower and higher frequencies in Nyquistplots increased after the addition of $\mathrm{TN}_{15} \mathrm{D}, \mathrm{TN}_{15} \mathrm{H}$, $\mathrm{TN}_{15} \mathrm{O}, \mathrm{TN}_{15} \mathrm{~L}$ inhibitors into the aggressivesolution. At lower inhibitor concentration, there is only adsorption of molecules on cathodic and/or anodic sites. This adsorption decreases the active centres on the metal surface. This is more pronounced with the increase in concentrationof the inhibitors, which can be attributed to the increase in the thickness of inhibitor layer by increasing the concentration. This layer acts as a barrier forthe ions and the electrons pass.The EIS data were analyzed by fitting the equivalent circuitmodel shown in Fig. 5 which fits well with the experimentalresults $\left(R^{2}=0.98-0.95\right)$. The circuits comprise a solution resistance $R_{s}$, in series withthe circuit comprises a charge transfer resistance $\left(\mathrm{R}_{\mathrm{ct}}\right)$ and CPE which is a constant phase element.CPE is mathematically expressed as in Eq. 10 (Banerjee et al., 2012; Mar et al., 2012):

$$
Z_{C P E}=Y_{\circ}^{-1}(i \omega)^{-n}
$$

where $Y$ 。 is a proportionality factor and ' $n$ ' has the meaning of phase shift. The value of ' $n$ ' represents the deviation from the ideal behaviour and it lies between 0 and 1 (Mar et al., 2012).

The Nyquist plots represented in Fig. 3a,bare not perfect semicircles as supposed in the theory of EIS.The Nyquist plots obtained in the real system represent a generalbehaviour where the double layer on the interface of metal/solutiondoes not behave as a real capacitor. On the metal side, electronscontrol the charge distribution, whereas on the solution side, it iscontrolled by ions. As ions are much larger than the electrons, the equivalent ions to the charge on the metal will occupy quitea large volume on the solution side of the double layer (Ozcan et al., 2004). Therefore,CPE used in place of double layer capacitance, $\mathrm{C}_{\mathrm{dl}}$, to representthe nonideal capacitive behaviour of the double layer.The data obtained from the equivalent circuit are presented in Table 4. The data show that $\mathrm{R}_{\mathrm{ct}}$ value were increased from $98.15 \Omega \mathrm{cm}^{-2}$ for the blank to $530,504,648.7$ and $592.3 \Omega \mathrm{cm}^{-2}$, respectively, after the addition of $400 \mathrm{ppm}$ by weight of $\mathrm{TN}_{15} \mathrm{D}, \mathrm{TN}_{15} \mathrm{H}, \mathrm{TN}_{15} \mathrm{O}, \mathrm{TN}_{15} \mathrm{Linhibitors}$. The increase in $R_{c t}$ values is attributed to the formation of an insulating protective film at the metal/solution interface. The decrease in $\mathrm{C}_{\mathrm{dl}}$ values can be attributed to a decrease in local dielectric constant and/or to an 
increase in the thickness of the electrical double layer, suggesting that the inhibitor molecules are adsorbed at the metal/solution interface (Umoren et al., 2010; Badr, 2009; Okafor and Zheng, 2009).

The double layer formed between the charged carbon steel surface and theinhibitor solution is considered as an electrical capacitor. The adsorption ofthe inhibitor molecules on the carbon steel surface decrease the electrical capacity becausethey displace the water molecules and the ions are originally adsorbedon the surface (Amin et al., 2010; Avci, 2008). Similar trend was observed by increasing the alkyl chain length from 10 methylene group in case of $\mathrm{TN}_{15} \mathrm{D}$ to 16 methylene group in $\mathrm{TN}_{15} \mathrm{D}, \mathrm{C}_{\mathrm{dl}}$ values decreased from $21.6 \mu \mathrm{F}$ $\mathrm{cm}^{-2}$ to $19.5 \mu \mathrm{F} \mathrm{cm}$ at $400 \mathrm{ppm}$ by weight. The lowest $\mathrm{C}_{\mathrm{dl}}$ value was $14.1 \mu \mathrm{F} \mathrm{cm}{ }^{-2}$, corresponds to $\mathrm{TN}_{15} \mathrm{~L}$ inhibitor at $400 \mathrm{ppm}$ by weight which contains 16 methylene groups and one double bond (Umoren et al., 2010; Lebrini et al., 2007). Furthermore, the thickness of the protective layer increased with theincrease in the inhibitor concentrations as understood from the gradual decrease in $\mathrm{C}_{\mathrm{dl}}$ by the gradual increase in the inhibitors concentration.

\section{Mechanism of inhibition}

Adsorption of inhibitor molecules on the metal surface is either physical or chemical adsorption(Negm et al., 2011). In the physical adsorption (physisorption)of inhibitors on the metal surface, there must be interactions between metal surface and the moleculesvia relatively weak interactions, e.g. dipole-dipole interactions(Negm et al., 2011). Whilein case of chemical adsorption (chemisorption)(Negm et al., 2012), itoccurs by the sharing of electrons ininhibitor molecules and metals, or the transfer of charges/electrons from the inhibitor molecules to metal surface. Considering the chemical structures of the tested inhibitors in the present work, there are four types of adsorptions. Firstly, the metal surface becomes negatively charged by adsorbing sulfate anions $\left(\mathrm{SO}_{4}^{--}\right)$on the surface (Pavithra, 2010). So, there are electrostatic interactions between negatively charged surface and positively charged atoms, which retard the anodic dissolution of iron (Aramaki et al., 1987). Secondly, according to the donor-acceptor interaction concept(Negm et al., 2012), $\pi$-electrons of the benzene rings and the double bond of the oleate derivative $\left(\mathrm{TN}_{15} \mathrm{~L}\right)$ in the inhibitor molecules can interact with vacant d-orbital of the metal surface (Hackerman et al., 1966).Thirdly, the polyethylene glycol groups of nonionic chains can adsorb on the metal surface through H-bonding, involving the displacement of water molecules from the metal surface. Lastly, the neutral parts of the molecules can then adsorb, onto metal surface when free surface areas are available.From Table 1, it is seen that at low concentration of the different inhibitors, i.e. 50 ppm by weight, the $\eta(\%)$ values depend strongly on the type of the alkyl chain length attached to the molecules. $\eta(\%)$ of $\mathrm{TN}_{15} \mathrm{D}, \mathrm{TN}_{15} \mathrm{H}$ and $\mathrm{TN}_{15} \mathrm{O}$ inhibitors were $90.2,91.8$ and $92.3 \%$, respectively. While in case of the oleic derivative $\left(\mathrm{TN}_{15} \mathrm{~L}\right)$, the efficiency increased remarkably $(95.0 \%)$ due to the presence of the unsaturation in the alkyl chain.The adsorption of the inhibitor molecules on the metal surface is represented in Figure 6. The adsorption of the alkyl chains (Fig. 6A) is achieved through the $\pi$-orbital of double bond and the vacant d-orbital of metal(Negm and Zaky, 2008; Negm et al., 2012), which might cover the steel surface more effectively and, thus, enhance the corrosion inhibition. Also, that overlap occurs in case of the benzene rings (Fig. 6B). In case of short alkyl chain $\left(\mathrm{TN}_{15} \mathrm{D}\right)$, the geometrical factor restricts the chains orientation and prevents their regular adsorption at the interface, which is responsible for the relatively low inhibition efficiency. In case of long chains, the alkyl chain starts to be located in on the metal surface (Ali et al., 2005).

\section{References}

[1]. Abdel-Rehim S.S., Ibrahim M.A.M., Khaled K.F., 2001. Mater. Chem. Phys. 70, 268-273.

[2]. Ali S.A., El-Shareef A.M., Al-Ghamdi R.F., Saeed M.T., 2005. Corros. Sci. 47, 2659-2678.

[3]. Ameer M.A., Fekry A.M., 2010. Corrosion inhibition of mild steel in acidic media using newly synthesized heterocyclic organic molecules. Int. J. Hydrogen Energy 35, 11387-11396.

[4]. Amin M.A., Khaled K.F., Fadl-Allah S.A., 2010. Testing validity of the Tafel extrapolation method for monitoring corrosion of cold rolled steel in $\mathrm{HCl}$ solutions-experimental and theoretical studies.Corros. Sci. 52, 140-151.

[5]. Aramaki K., Hagiwara N., Nishihara H., 1987. Corros. Sci. 27, 487-497.

[6]. Asefi D., Arami M., Sarabi A.A., Mahmoodi N.M., 2009. The chain length influence of cationic surfactant and role of nonionic cosurfactants on controlling the corrosion rate of steel in acidic media.Corros. Sci. 51, 1817-1821.

[7]. Asefi D., Mahmoodi N.M., Arami M., 2010. Effect of nonionic co-surfactants on corrosion inhibition effect of cationic Gemini surfactant. Colloids Surf. A. 355, 183-186.

[8]. ASTM G3-89, standard practice for conventions applicable to electrochemical measurements in corrosion testing, 1994

[9]. ASTM G 31-72, Standard practice for laboratory immersion corrosion testing of metals, in: Annual Book of Standards, American Society for Testing and Materials, Philadelphia, PA, 1990.

[10]. Avci G., 2008. Inhibitor effect of N,N-methylenediacrylamide on corrosion behaviour of mild steel in $0.5 \mathrm{M} \mathrm{HCl}$. Mater. Chem. Phys. 112, 234-238.

[11]. Badr G.E., 2009. Corros.Sci. 51, 2529-2536.

[12]. Banerjee S., Srivastava V., Singh M.M., 2012. Chemically modified natural polysaccharide as green corrosion inhibitor for mild steel in acidic medium.Corros. Sci. 59, 35-41.

[13]. Behpour M., Ghoreishi S.M., Soltani N., Salavati-Niasari M., Hamadanian M., Gandomi A., 2008. Electrochemical and theoretical investigation on the corrosion inhibition of mild steel by thiosalicylaldehyde derivatives in hydrochloric acid solution.Corros.Sci. 50, 2172-2181.

[14]. Bentiss F., Lebrini M., Lagrenée M., 2005. Thermodynamic characterization of metal dissolution and inhibitor adsorption processes in mild steel/2,5-bis(n-thienyl)-1,3,4-thiadiazoles/hydrochloric acid system. Corros. Sci. 47, 2915-2931. 
[15]. Bentiss F., Mernari B., Traisnel M., Vezin H., Lagrenee M., 2011. On the relationship between corrosion inhibiting effect and molecular structure of 2,5-bis(npyridyl)-1,3,4-thiadiazole derivatives in acidic media: Ac impedance and DFT studies. Corros. Sci. $53,487-495$.

[16]. Bouklah M., Attayibat A., Kertit S., Ramdani A., Hammouti B., 2005. A pyrazine derivative as corrosion inhibitor for steel in sulphuric acid solution. Appl. Surf. Sci. 242, 399-406.

[17]. Chetouani A., Aouniti A., Hammouti B., Benchat N., Benhadda T., Kertit S., 2003. Corrosion inhibitors for iron in hydrochloride acid solution by newly synthesised pyridazine derivatives. Corros. Sci. 45, 1675-1684.

[18]. Cruz J., Pandiyan T., Garcìa-Ochoa E., 2005. A new inhibitor for mild carbon steel: Electrochemical and DFT studies. J. Electroanal. Chem. 583, 8-16.

[19]. Dehri I., Sozusaglam H., Erbil M., 2003. EIS study of the effect of high levels of $\mathrm{NH}_{3}$ on the deformation of polyester-coated galvanised steel at different relative humidity. Prog. Org. Coat. 48, 118-123.

[20]. El Achouri M., Kertit S., Gouttaya H.M., Nciri B., Bensouda Y., Perez L., Infante M.R., Elkacemi K., 2001. Corrosion inhibition of iron in $1 \mathrm{M} \mathrm{HCl}$ by some gemini surfactants in the series of alkanediyl-a, x-bis-(dimethyl tetradecyl ammonium bromide). Prog. Org. Coat. 43, 267-273.

[21]. Erbil M., 1988. The determination of corrosion rates by analysis of AC impedance diagrams. Chim. ActaTurc. 1, 59-70.

[22]. Fuchs-Godec R., 2009. Effects of surfactants and their mixtures on inhibition of the corrosion process of ferritic stainless steel. Electrochim. Acta 54, 2171-2179.

[23]. Fuchs-Godec R., 2010. The erosion-corrosion inhibition of AISI 431 martensitic stainless steel in $2 \mathrm{M} \mathrm{H}_{2} \mathrm{SO}_{4}$ solution using Nalkyl quaternary ammonium salts as inhibitors. Ind. Eng. Chem. Res. 49, 6407-6415.

[24]. Granese S.L., Rosales B.M., Oviedo C., Zerbino J.O., 1992.The inhibition action of heterocyclic nitrogen organic compounds on Fe and steel in $\mathrm{HCl}$ media.Corros. Sci. 33, 1439-1453.

[25]. Gust J., 1991. Application of infrared spectroscopy for investigation of rust phase component conversion by agents containing oak tannin and phosphoric acid. NACE 47, 453-457.

[26]. Hsu C.H., Mansfeld F., 2001. Corros. J. 57, 747-752.

[27]. Hassan H.H., 2005. Electrochim. Acta 51, 526-534.

[28]. Hackerman N., SnavelyJr.E., Payne Jr. J.S., 1966. J. Appl. Electrochem. 113, 677-681.

[29]. Hassan H.H., Abdelghani E., Amin M.A., 2007. Inhibition of mild steel corrosion in hydrochloric acid solution by triazole derivatives.Part I. Polarisation and EIS studies.Electrochim.Acta 52, 6359-6366.

[30]. Hegazy M.A., Abdallah M., Ahmed H., 2010. Corros.Sci. 52, 2897-2904.

[31]. Hosseini S.M.A., Azimi A., 2009. The inhibition of mild steel corrosion in acidic medium by 1- methyl-3-pyridin-2-ylthiourea.Corros. Sci. 51, 728-732.

[32]. Jaen J.A., Saldana G., Hernandez C., 1999. Characterization of reaction products of iron and aqueous plant extracts. Hyperfine Interactions, 122, 139-145.

[33]. Lebrini M., Lagrenee M., Vezin H., Gengembre L., Bentiss F., 2005. Corros. Sci. 47, 485-492.

[34]. Lebrini M., Lagrenee M., Vezin H., Traisnel M., Bentiss F., 2007. Experimental and theoretical study for corrosion inhibition of mild steel in normal hydrochloric acid solution by some new macrocyclic polyether compounds. Corros. Sci. 49, 2254-2269.

[35]. Lebrini M., Robert F., Vezin H., Roos C., 2010. Electrochemical and quantum chemical studies of some indole derivatives as corrosion inhibitors for C38 steel in molar hydrochloric acid. Corros. Sci. 52, 3367-3376.

[36]. Li W., He Q., Zhang S., Pei C., Hou B., 2008. J. Appl. Electrochem 38, 289-295.

[37]. Li W., Zhao X., Liu F., Hou B., 2008. Investigation on inhibition behavior of trizaole derivatives in acidic solution.Corros.Sci. 50, 3261-3266.

[38]. Liu F.G., Du M., Zhang J., Qiu M., Corros. Sci. 51 (2009) 102-109.

[39]. Luo H., Guan Y.C., Han K.N., 1998. Corrosion inhibition of a mild steel by aniline and alkylamine in acidic solutions. Corrosion 54, 721-731.

[40]. Machnikova E., Whitmire K.H., Hackerman N., 2008. Electrochim.Acta 53, 6024-6032.

[41]. Mar L., Xometl O., Aguilar M., Flores E., Lozada P., Cruz F., 2012. Corrosion inhibitor activity of 1,3-diketone malonates for mild steel in aqueous hydrochloric acid solution. Corros. Sci. 61, 171-184.

[42]. McCafferty E., 1997. Corros. Sci. 39, 243-254.

[43]. McCafferty E., 2005. Corros.Sci. 47, 3202-3215.

[44]. Musa A.Y., Kadheem A.H., Mohamod A.B., Takriff M.S., Daud A.R., Kamaruddin S.K., 2010. Corros. Sci. 52, $526-533$.

[45]. Negm N.A.,Badr E.A., Aiad I.A., Zaki M.F., SaidM.M., 2012. Investigation the inhibitory action of novel diquaternary Schiff dibases on the acid dissolution of carbon steel in $1 \mathrm{M}$ hydrochloric acid solution, Corros. Sci. 65, 77-86.

[46]. Negm N.A., El Farargy A.F.M., Mohammed D.E., Mohammad H.N., 2012. Environmentally friendly nonionic surfactants derived from tannic acid: synthesis, characterization and surface activity. J. Surfact. Deterg. 15, 433-443.

[47]. Negm N.A., Kandile N.G., Aiad I.A., Mohammad M.A., 2011. New eco-friendly cationic surfactants: synthesis, characterization and applicability as corrosion inhibitors for carbon steel in $1 \mathrm{~N} \mathrm{HCl}$. Colloids and Surf. A: Physicochem. Eng. Aspects 391, 224233.

[48]. Negm N.A., Kandile N.G., Badr E.A., Mohammed M.A., 2012. Gravimetric and electrochemical evaluation of environmentally friendly nonionic corrosion inhibitors for carbon steel in 1M HCl. Corros. Sci. 65, 94-103.

[49]. Negm N.A., Zaky F.M., 2008. Corrosion inhibition efficiency of nonionic Schiff base amphiphiles of p-aminobenzoic acid for aluminum in $4 \mathrm{~N} \mathrm{HCl}$. Colloids Surf. A. 322, 97-102.

[50]. Noor E.A., Al-Moubaraki A.H., 2008. Thermodynamic study of metal corrosion and inhibitor adsorption processes in mild steel/1methyl-4-styryl pyridinium iodides/hydrochloric acid systems. Mater. Chem. Phys. 110, 145-154.

[51]. Obot I.B., Obi-Egbedi N.O., 2010. Adsorption properties and inhibition of mild steel corrosion in sulphuric acid solution by ketoconazole: experimental and theoretical investigation. Corros. Sci. 52, 198-204.

[52]. Okafor P.C., Zheng Y., 2009. Corros. Sci. 51, 850-859.

[53]. Ostovari A., Hoseinieh S.M., Peikari M., Shadizadeh S.R., Hashemi S.J., 2009. Corrosion inhibition of mild steel in $1 \mathrm{M} \mathrm{HCl}$ solution by henna extract: A comparative study of the inhibition by henna and its constituents. Corros. Sci.51, 1935-1944.

[54]. Ozcan M., Dehri I., Erbil M., 2004. Organic sulphur-containing compounds as corrosion inhibitors for mild steel in acidic media: correlation between inhibition efficiency and chemical structure. Appl. Surf. Sci. 236, 155-164.

[55]. Pardave M., Romero M., Hernandez H., Quijano M., Likhanova N., Uruchurtu J., Garcia J., 2012. Influence of the alkyl chain length of 2-amino-5-alkyl-1,3,4-thiadiazole compounds on the corrosion inhibition of steel immersed in sulfuric acid solutions. Corros. Sci. 54, 231-243.

[56]. Pavithra M.K., Venkatesha T.V., Vathsala K., Nayana K.O., 2010. Corros.Sci. 52, 3811-3819. 
[57]. Popova A., Sokolova E., Raicheva S., Christov M., 2003. Corros. Sci. 45, 33-58.

[58]. Quartarone G., Bonaldo L., Battilana M., Tortato T., 2008. Investigation of the inhibition effect of indole-3- carboxylic acid on the copper corrosion in $0.5 \mathrm{M} \mathrm{H}_{2} \mathrm{SO}_{4}$.Corros.Sci. 50, 3467-3474.

[59]. Quartarone G., Bonaldo L., Tortato C., 2006. Inhibitive action of indole-5-carboxylic acid towards corrosion of mild steel in deaerated 0.5 M sulfuric acid solutions. Appl. Surf. Sci. 252, 8251-8257.

[60]. Quraishi M.A., Ahmad S., Ansari M.Q., 1997. Inhibition of steel corrosion by some new triazole derivatives in boiling hydrochloric acid. Br. Corros. J. 32, 297-300.

[61]. Quraishi M.A., Jamal D., 2000. The influence of some condensation products on corrosion inhibition of mild steel in acidic solutions.Anti-Corros.Meth.Mater. 47, 233-241.

[62]. Rahim A.A., Rocca E., Steinmetz J., Kassim M.J., 2008. Inhibitive action of mangrove tannins and phosphoric acid on pre-rusted steel via electrochemical methods. Corros. Sci. 50, 1546-1550.

[63]. Shukla S.K., Quraishi M.A., 2009. Corros. Sci. 51, 1007-1011.

[64]. Singh A.K., Quraishi M.A., 2009. Corros.Sci. 51, 2752-2760.

[65]. Solmaz R., Kardas G., Culha M., Yazici B., Erbil M., 2008.Electrochim. Acta 53, 5941-5952.

[66]. Tebbji K., Oudda H., Hammouti B., Benkaddour M., El Kodadi M., Malek F., Ramdani A., 2005. Inhibitive action of two bipyrazolic isomers towards corrosion of steel in $1 \mathrm{M} \mathrm{HCl}$. Appl. Surf. Sci. 241, 326-334

[67]. Umoren S.A., Li Y., Wang F.H., 2010. Synergistic effect of iodide ion and polyacrylic acid on corrosion inhibition of iron in $\mathrm{H}_{2} \mathrm{SO}_{4}$ investigated by electrochemical techniques. Corros. Sci. 52, 2422-2429.

[68]. Valcarce M.B., Vazquez M., 2009. Mater. Chem. Phys. 115, 313-321.

[69]. Zhou X., Yang H., Wang F., 2012. Investigation on the inhibition behavior of a pentaerythritol glycoside for carbon steel in 3.5\% $\mathrm{NaCl}$ saturated $\mathrm{Ca}(\mathrm{OH})_{2}$ Solution. Corros. Sci. 54, 193-200.

Table 1. Corrosion rate ${ }^{\mathrm{a}}\left(\mathrm{C}_{\mathrm{r}}\right)$, surface coverage $(\theta)$ and inhibition efficiency $(\eta \%)$ of $\mathrm{TN}_{15} \mathrm{D}, \mathrm{TN}_{15} \mathrm{H}$, $\mathrm{TN}_{15} \mathrm{O}$ and $\mathrm{TN}_{15} \mathrm{~L}$ inhibitors/carbon steel in $0.5 \mathrm{M} \mathrm{H}_{2} \mathrm{SO}_{4}$ at different concentrations and at different immersion times obtained by weight loss measurementsat $25^{\circ} \mathrm{C}$

\begin{tabular}{|c|c|c|c|c|c|c|c|c|c|c|}
\hline \multirow[b]{2}{*}{ Inhibitor } & \multirow{2}{*}{$\begin{array}{l}\text { Concentration } \\
\text { (ppm by weight) }\end{array}$} & \multicolumn{3}{|c|}{$3 \mathrm{~h}$} & \multicolumn{3}{|c|}{$6 \mathrm{~h}$} & \multicolumn{3}{|c|}{$24 h$} \\
\hline & & $\begin{array}{c}\mathrm{C}_{\mathrm{r}}, \\
\left(\mathrm{mg} \mathrm{cm}^{2} \mathrm{~h}^{-1}\right)\end{array}$ & $\theta$ & $\eta \%$ & $\begin{array}{c}\mathrm{C}_{\mathrm{r}}, \\
\left(\mathrm{mg} \mathrm{cm}^{2} \mathrm{~h}^{-1}\right)\end{array}$ & $\theta$ & $\eta \%$ & $\begin{array}{c}\mathrm{C}_{\mathrm{r}}, \\
\left(\mathrm{mg} \mathrm{cm}^{2} \mathrm{~h}^{-1}\right)\end{array}$ & $\theta$ & $\eta \%$ \\
\hline Blank & 0.0 & 4.40 & 0.0 & 0.0 & 3.37 & 0.0 & 0.0 & 3.32 & 0.0 & 0.0 \\
\hline \multirow{4}{*}{$\mathrm{TN}_{15} \mathrm{D}$} & 50 & 0.51 & 0.87 & 87.1 & 0.44 & 0.88 & 88.3 & 0.29 & 0.91 & 91.3 \\
\hline & 100 & 0.39 & 0.90 & 90.1 & 0.35 & 0.91 & 90.7 & 0.24 & 0.93 & 92.8 \\
\hline & 200 & 0.30 & 0.92 & 92.4 & 0.26 & 0.93 & 93.1 & 0.17 & 0.95 & 94.9 \\
\hline & 400 & 0.22 & 0.94 & 94.4 & 0.19 & 0.95 & 95.0 & 0.13 & 0.96 & 96.1 \\
\hline \multirow{4}{*}{$\mathrm{TN}_{15} \mathrm{H}$} & 50 & 0.45 & 0.89 & 88.6 & 0.39 & 0.90 & 89.7 & 0.25 & 0.91 & 91.4 \\
\hline & 100 & 0.38 & 0.90 & 90.4 & 0.31 & 0.92 & 91.8 & 0.18 & 0.93 & 93.2 \\
\hline & 200 & 0.28 & 0.93 & 92.9 & 0.24 & 0.94 & 93.6 & 0.14 & 0.96 & 95.6 \\
\hline & 400 & 0.20 & 0.95 & 94.9 & 0.13 & 0.97 & 96.6 & 0.09 & 0.97 & 97.3 \\
\hline \multirow{4}{*}{$\mathrm{TN}_{15} \mathrm{O}$} & 50 & 0.41 & 0.90 & 89.6 & 0.29 & 0.92 & 92.3 & 0.16 & 0.95 & 95.2 \\
\hline & 100 & 0.31 & 0.92 & 92.1 & 0.24 & 0.94 & 93.6 & 0.11 & 0.97 & 96.7 \\
\hline & 200 & 0.22 & 0.94 & 94.4 & 0.18 & 0.95 & 95.2 & 0.03 & 0.99 & 99.1 \\
\hline & 400 & 0.15 & 0.96 & 96.2 & 0.1 & 0.97 & 97.3 & 0.03 & 0.99 & 99.1 \\
\hline \multirow{4}{*}{$\mathbf{T N}_{15} \mathbf{L}$} & 50 & 0.37 & 0.91 & 90.6 & 0.25 & 0.93 & 93.4 & 0.11 & 0.97 & 96.7 \\
\hline & 100 & 0.29 & 0.93 & 92.6 & 0.18 & 0.95 & 95.2 & 0.08 & 0.98 & 97.6 \\
\hline & 200 & 0.18 & 0.95 & 95.4 & 0.09 & 0.98 & 97.6 & 0.02 & 0.99 & 99.4 \\
\hline & 400 & 0.14 & 0.96 & 96.4 & 0.08 & 0.98 & 97.9 & 0.02 & 0.99 & 99.4 \\
\hline
\end{tabular}

${ }^{\mathrm{a}}$ Values were average of three trials with error ratio of $6 \%$.

Table 2. Polarisation parameters for the corrosion of carbon steel in $0.5 \mathrm{M} \mathrm{H}_{2} \mathrm{SO}_{4}$ containing different concentration of $\mathrm{TN}_{15} \mathrm{D}, \mathrm{TN}_{15} \mathrm{H}, \mathrm{TN}_{15} \mathrm{O}$ and $\mathrm{TN}_{15} \mathrm{~L}$ inhibitors at $25^{\circ} \mathrm{C}$

\begin{tabular}{|c|c|c|c|c|c|c|c|}
\hline Inhibitor & $\begin{array}{l}\text { Concentration } \\
\text { (ppm by weight) }\end{array}$ & $\begin{array}{c}\mathbf{E}_{\text {corr }} \text { vs. SCE, } \\
(\mathrm{mV})\end{array}$ & $\begin{array}{c}\mathbf{R}_{\mathrm{p}} \\
\left(\Omega \mathbf{c m}^{2}\right)\end{array}$ & $\begin{array}{c}\mathbf{i}_{\text {corr }} \\
\left(\mathbf{m A ~ c m} \mathbf{~ c m}^{-2}\right)\end{array}$ & $\begin{array}{c}\beta_{a} \\
\left(\mathbf{m V} \mathbf{d e c}^{-1}\right)\end{array}$ & $\begin{array}{c}\boldsymbol{\beta}_{\mathrm{c}} \\
\left(\mathbf{m V} \mathbf{d e c}^{-1}\right)\end{array}$ & $\eta(\%)$ \\
\hline Blank & 0.0 & -575.6 & 0.430 & 0.439 & 224.8 & -323.2 & 0.0 \\
\hline \multirow{4}{*}{$\mathbf{T N}_{15} \mathrm{D}$} & 50 & -576.1 & 294.2 & 0.043 & 225.4 & -158.7 & 90.2 \\
\hline & 100 & -575.4 & 285.6 & 0.031 & 229.6 & -169.1 & 92.9 \\
\hline & 200 & -590.7 & 287.8 & 0.029 & 237.1 & -143.1 & 93.4 \\
\hline & 400 & -602.1 & 304.6 & 0.024 & 226.2 & -167.3 & 94.5 \\
\hline \multirow{4}{*}{$\mathbf{T N}_{15} \mathbf{H}$} & 50 & -559.9 & 183.8 & 0.036 & 160.8 & -167.1 & 91.8 \\
\hline & 100 & -567.5 & 288.8 & 0.028 & 175.7 & -172.6 & 93.6 \\
\hline & 200 & -583.7 & 326.8 & 0.024 & 183.1 & -152.5 & 94.5 \\
\hline & 400 & -596.5 & 567.7 & 0.020 & 168.5 & -126.3 & 95.4 \\
\hline \multirow{4}{*}{$\mathbf{T N}_{15} \mathrm{O}$} & 50 & -582.3 & 270.8 & 0.034 & 124.0 & -161.5 & 92.3 \\
\hline & 100 & -587.2 & 592.7 & 0.031 & 136.0 & -152.2 & 92.9 \\
\hline & 200 & -618.5 & 590.4 & 0.027 & 130.6 & -137.3 & 93.8 \\
\hline & 400 & -645.1 & 535.6 & 0.023 & 145.7 & -136.7 & 94.8 \\
\hline \multirow{4}{*}{$\mathbf{T N}_{15} \mathbf{L}$} & 50 & -559.2 & 154.1 & 0.022 & 218.7 & -170.8 & 95.0 \\
\hline & 100 & -570.9 & 315.8 & 0.020 & 205.6 & -167.6 & 95.4 \\
\hline & 200 & -594.1 & 403.5 & 0.017 & 204.5 & -144.5 & 96.1 \\
\hline & 400 & -603.3 & 540.3 & 0.012 & 207.8 & -150.5 & 97.3 \\
\hline
\end{tabular}


Table 3. Thermodynamic parameters from Langmuir adsorption isotherm for the adsorption of $\mathbf{T N}_{15} \mathrm{D}$, $\mathrm{TN}_{15} \mathrm{H}, \mathrm{TN}_{15} \mathrm{O}$ and $\mathrm{TN}_{15} \mathrm{~L}$ inhibitors on the carbon steel surface in $0.5 \mathrm{M} \mathrm{H}_{2} \mathrm{SO}_{4}$ solution

\begin{tabular}{ccccc}
\hline Inhibitor & Slope $^{\mathbf{a}}$ & $\begin{array}{c}\text { Regression coefficient, } \\
\mathbf{R}^{\mathbf{2}}\end{array}$ & $\begin{array}{c}\mathbf{K}_{\text {ads }} \\
\left(\mathbf{1 0}^{\mathbf{4}} \mathbf{M}^{\mathbf{1}}\right)\end{array}$ & $\begin{array}{c}\Delta \mathbf{G}_{\text {ads }}^{\circ} \\
\mathbf{k J ~ m o l}^{\mathbf{- 1}}\end{array}$ \\
\hline $\mathbf{T N}_{\mathbf{1 5}} \mathbf{D}$ & 1.009 & 1.0 & 9.91 & 32.67 \\
$\mathbf{T N}_{\mathbf{1 5}} \mathbf{H}$ & 1.008 & 1.0 & 9.92 & 32.70 \\
$\mathbf{T N}_{\mathbf{1 5}} \mathbf{O}$ & 1.006 & 1.0 & 9.93 & 32.72 \\
$\mathbf{T N}_{\mathbf{1 5}} \mathbf{L}$ & 1.004 & 0.999 & 9.95 & 32.75 \\
\hline${ }^{\mathrm{a}}$ Values were average of three trials with error ratio of $6 \%$.
\end{tabular}

Table 4. Electrochemical impedance parameters for the corrosion of carbon steel in $0.5 \mathrm{M} \mathrm{H}_{2} \mathrm{SO}_{4}$ containing different concentration of $\mathrm{TN}_{15} \mathrm{D}, \mathrm{TN}_{15} \mathrm{H}, \mathrm{TN}_{15} \mathrm{O}$ and $\mathrm{TN}_{15} \mathrm{~L}$ inhibitors

\begin{tabular}{|c|c|c|c|c|c|}
\hline Inhibitor & $\begin{array}{l}\text { Concentration } \\
\text { (ppm by weight) }\end{array}$ & $\begin{array}{c}R_{\mathrm{s}} \\
\left(\Omega \mathrm{cm}^{2}\right)\end{array}$ & 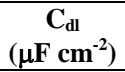 & $\begin{array}{c}\mathbf{R}_{\mathrm{ct}} \\
\left(\Omega \mathrm{cm}^{2}\right)\end{array}$ & $\eta(\%)$ \\
\hline Blank & 0.0 & 4.7 & 395 & 98.15 & 0.0 \\
\hline \multirow{4}{*}{$\mathrm{TN}_{15} \mathrm{D}$} & 50 & 10.4 & 32.1 & 122.1 & 91.9 \\
\hline & 100 & 9.3 & 29.9 & 428.5 & 92.4 \\
\hline & 200 & 6.2 & 26.5 & 488.2 & 93.3 \\
\hline & 400 & 5.8 & 21.6 & 530.0 & 94.5 \\
\hline \multirow{4}{*}{$\mathbf{T N}_{15} \mathbf{H}$} & 50 & 6.0 & 28.7 & 192.3 & 92.7 \\
\hline & 100 & 5.9 & 27.2 & 307.7 & 93.1 \\
\hline & 200 & 5.8 & 25.3 & 353.7 & 93.6 \\
\hline & 400 & 4.9 & 21.3 & 504.0 & 94.6 \\
\hline \multirow{4}{*}{$\mathrm{TN}_{15} \mathrm{O}$} & 50 & 5.6 & 24.5 & 306.0 & 93.8 \\
\hline & 100 & 5.2 & 23.6 & 486.7 & 94.0 \\
\hline & 200 & 3.8 & 21.9 & 548.9 & 94.5 \\
\hline & 400 & 3.5 & 19.5 & 648.7 & 95.1 \\
\hline \multirow{4}{*}{$\mathbf{T N}_{15} \mathrm{~L}$} & 50 & 8.2 & 21.7 & 211.7 & 94.5 \\
\hline & 100 & 6.7 & 19.5 & 375.4 & 95.1 \\
\hline & 200 & 4.2 & 17.7 & 529.4 & 95.5 \\
\hline & 400 & 3.8 & 14.1 & 592.3 & 96.4 \\
\hline
\end{tabular}

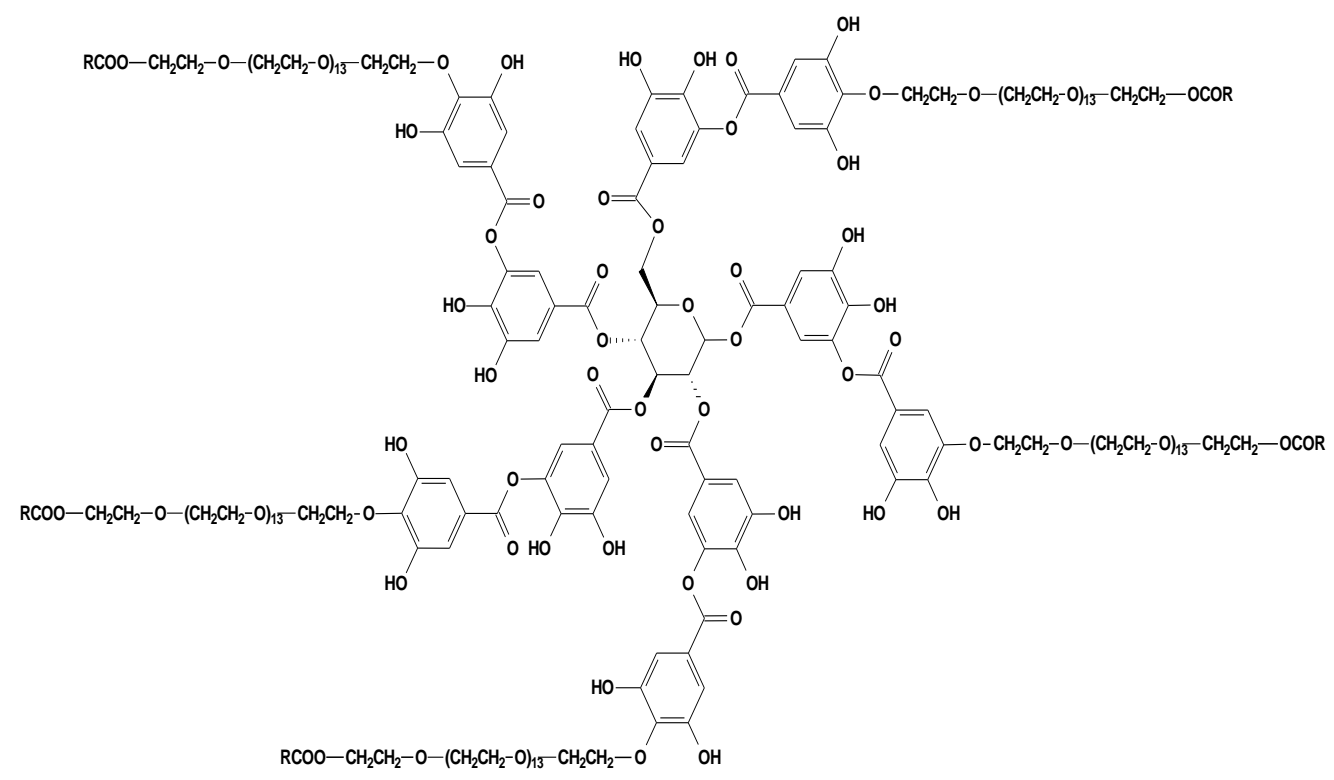

$$
\begin{gathered}
\mathrm{R}=\mathrm{C}_{11} \mathrm{H}_{23} \text { (Dodecanoic acid), } \\
\mathrm{C}_{15} \mathrm{H}_{31} \text { (Hexadecanoic acid), } \\
\mathrm{C}_{17} \mathrm{H}_{35} \text { (Octadecanoic acid), } \\
\mathrm{C}_{17} \mathrm{H}_{33} \text { (Oleic acid). }
\end{gathered}
$$

Fig.1.Chemical structure of the tested inhibitors $\left(\mathrm{TN}_{15} \mathrm{D}, \mathrm{TN}_{15} \mathrm{H}, \mathrm{TN}_{15} \mathrm{O}, \mathrm{TN}_{15} \mathrm{~L}\right)$, where: $\mathrm{TN}$ refer to tannic acid polyethylene glycol, and $\mathrm{D}, \mathrm{H}, \mathrm{O}, \mathrm{L}$ refer to the alkyl chains $(\mathrm{R})$. 


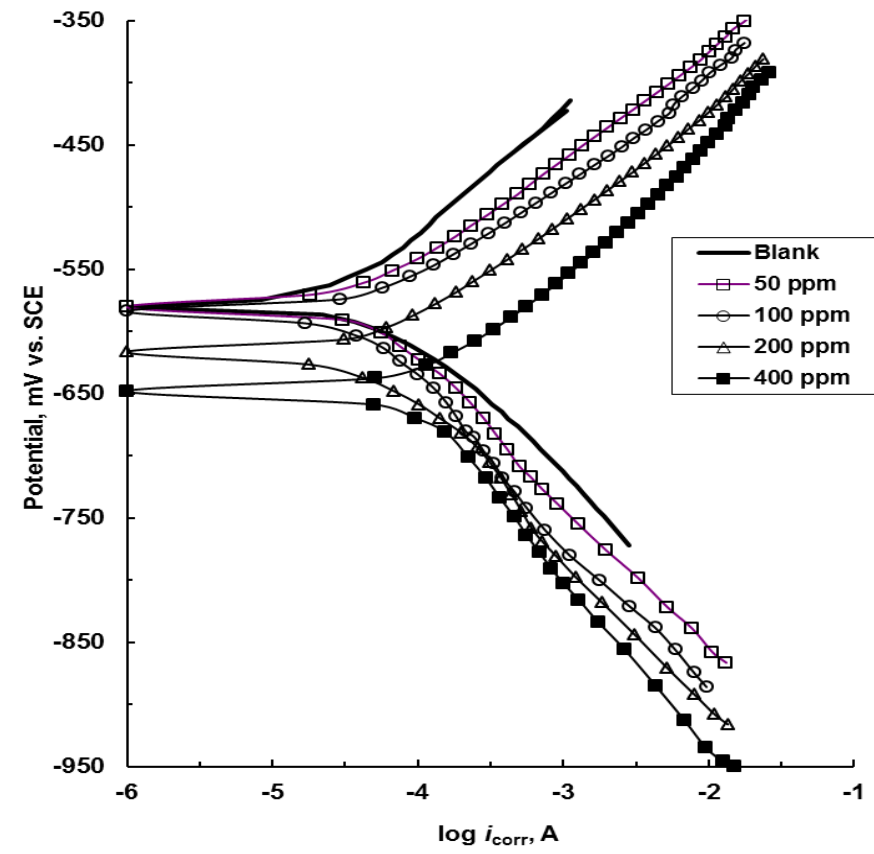

Fig. 2a.Polarization curve of carbon steel corrosion in $0.5 \mathrm{M} \mathrm{H}_{2} \mathrm{SO}_{4}$ in presence of different concentrations (ppm by weight) of $\mathrm{TN}_{15} \mathrm{O}$ inhibitor at $25^{\circ} \mathrm{C}$.

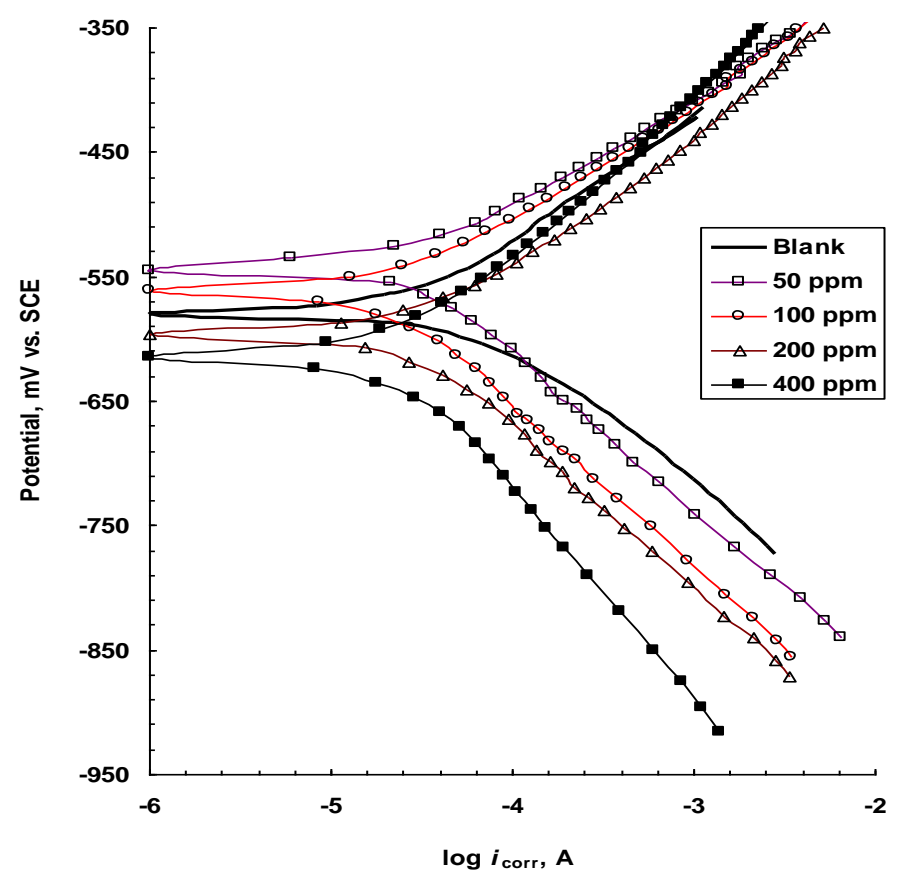

Fig. 2b.Polarization curve of carbon steel corrosion in $0.5 \mathrm{M} \mathrm{H}_{2} \mathrm{SO}_{4}$ in presence of different concentrations (ppm by weight) of $\mathrm{TN}_{15} \mathrm{~L}$ inhibitor at $25^{\circ} \mathrm{C}$. 


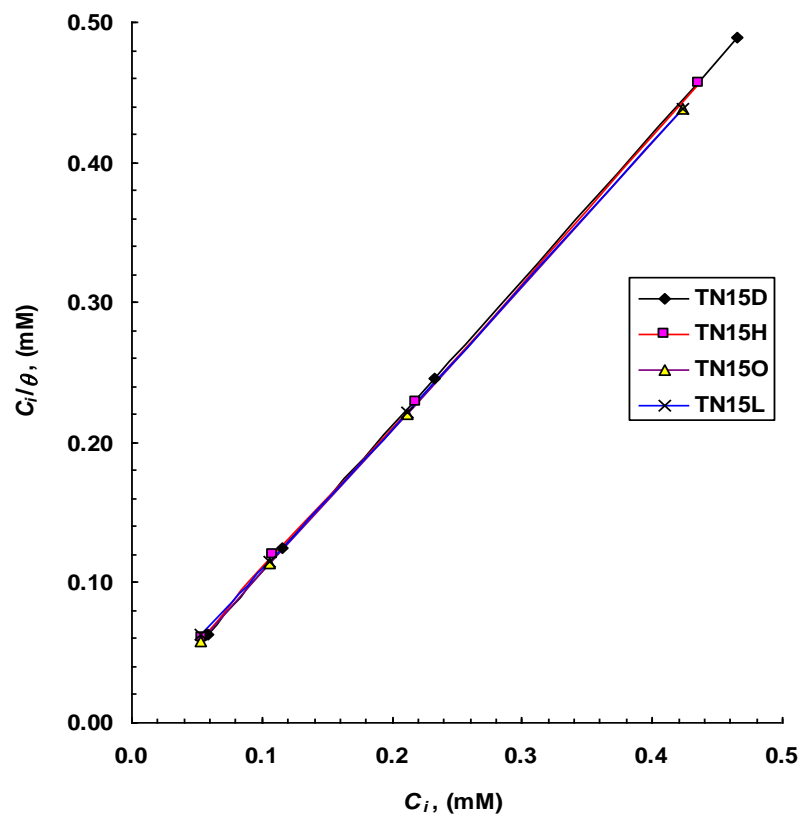

Fig. 3. Langmuir adsorptionisotherm of $\mathrm{TN}_{15} \mathrm{D}, \mathrm{TN}_{15} \mathrm{H}, \mathrm{TN}_{15} \mathrm{O}, \mathrm{TN}_{15} \mathrm{~L}$ inhibitors on the surface of carbon steel in $0.5 \mathrm{M} \mathrm{H}_{2} \mathrm{SO}_{4}$ at $25^{\circ} \mathrm{C}$ obtained from weight loss data after $24 \mathrm{~h}$, values are average of three trials with error ratio of $6 \%$.

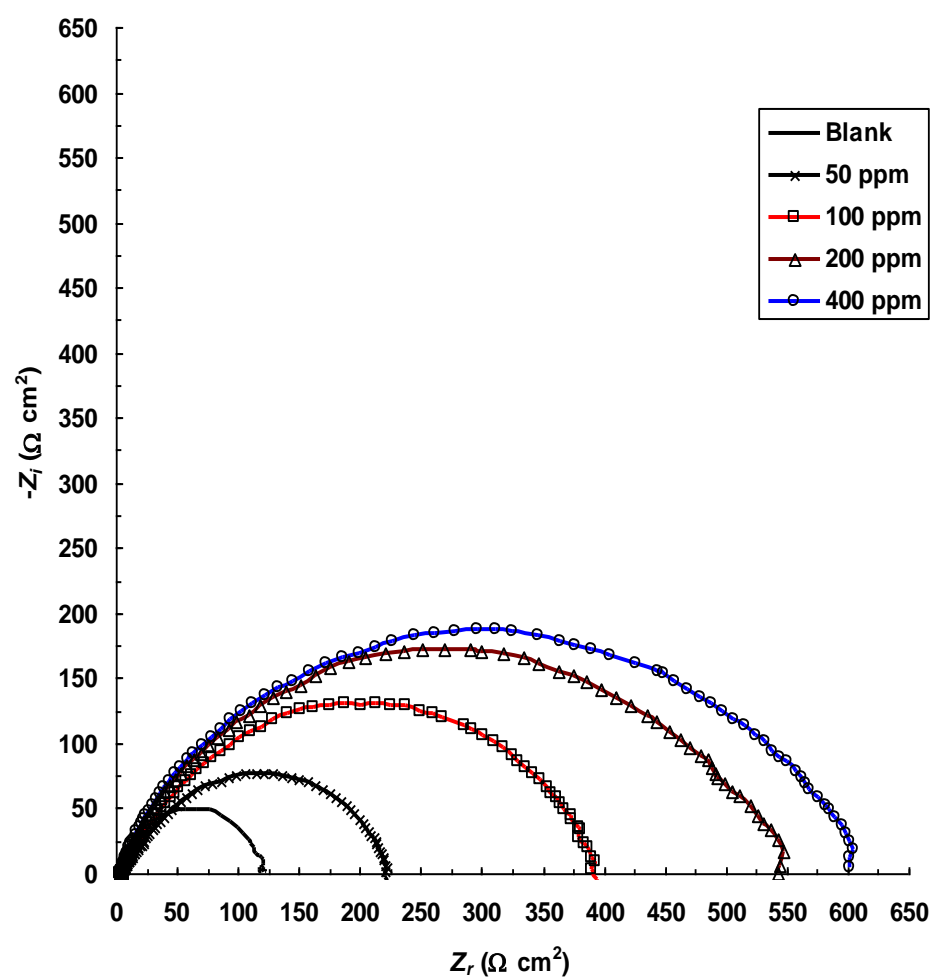

Fig. 4a. Nyquist plots of carbon steel corrosion in $0.5 \mathrm{M} \mathrm{H}_{2} \mathrm{SO}_{4}$ in presence of different concentrations (ppm by weight) of $\mathrm{TN}_{15} \mathrm{O}$ inhibitor at $25^{\circ} \mathrm{C}$. 


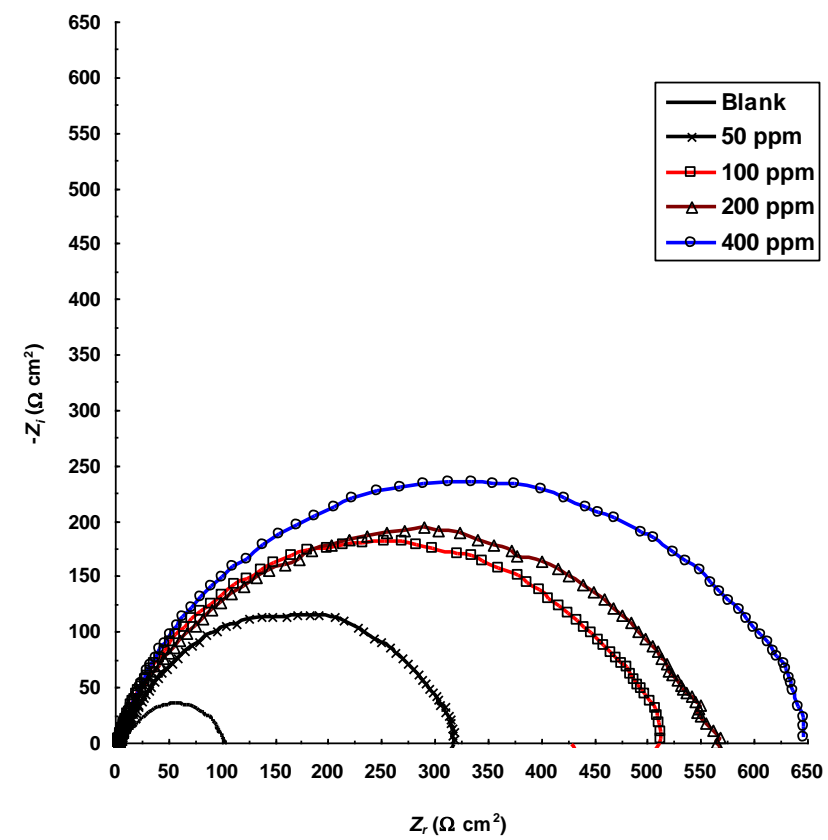

Fig. 4b. Nyquist plots of carbon steel corrosion in $0.5 \mathrm{M} \mathrm{H}_{2} \mathrm{SO}_{4}$ in presence of different concentrations (ppm by weight) of $\mathrm{TN}_{15} \mathrm{~L}$ inhibitor at $25{ }^{\circ} \mathrm{C}$.

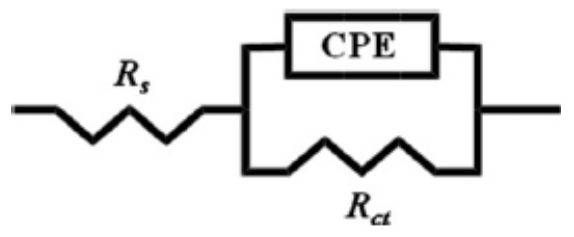

Fig. 5. Equivalent circuit fits the electrochemical impedance measurements

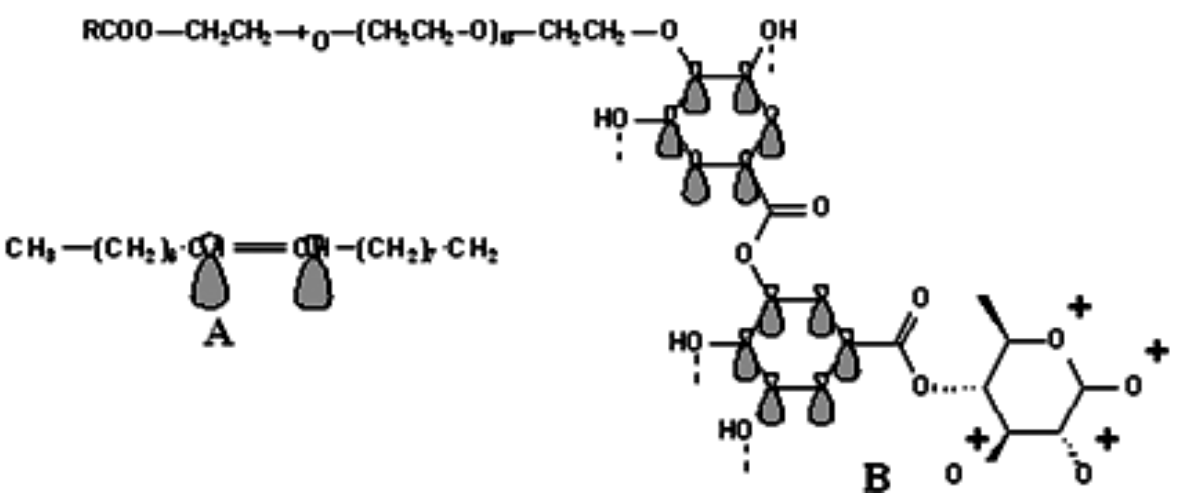

Fig. 6.Adsorption of the inhibitor molecules on the carbon steel surface. 